UDC 547.279

\title{
CYANALKYLATION OF MERCAPTOACETIC ACID ESTERS
}

\author{
K.Z.Guseinov, *M.A.Mirzoyeva, P.A.Aliyev \\ Baku State University \\ gasimhuseynov@bsu.edu.az. \\ *A.Guliyev Institute of Chemistry of Additives, NAS of Azerbaijan \\ mziya-m@rambler.ru \\ Received 07.06.2021 \\ Accepted 30.07.2021
}

\begin{abstract}
The addition of mercaptoacetic acid esters (MAAE) to nitriles of acrylic, methacrylic, and crotonic acids easily occurs in the presence of triethylamine as a catalyst to form the corresponding 2-cyanoalkylalkoxycarbonylmethyl sulfides.
\end{abstract}

Keywords: esters of mercaptoacetic acid, sulfide, nitriles of acrylic-, methacrylic- and crotonic acids.

doi.org/10.32737/0005-2531-2021-4-30-34

\section{Introduction}

A number of methods for the synthesis of organosulfur compounds are known, among which synthesis based on thiols is of great importance. Having an active hydrogen atom in their molecule, thiols easily react with unsaturated compounds to form various sulfides [1-3].

Previously, we studied the influence of organosulfur compounds obtained on the basis of various thiols on the anticorrosive properties of motor oils, and for the first time it was found that compounds containing the $-\mathrm{SCH}_{2} \mathrm{COOR}$ fragment ( $\mathrm{R}$ - aliphatic radicals) in the molecule are much more effective than other sulfides [4].
Of undoubted interest are the synthesis of MAAE derivatives containing, in addition to sulfide sulfur in the molecule, the -COOR group, as well as the $-\mathrm{CH}_{2} \mathrm{CH}_{2} \mathrm{CN}$ group, and the study of their influence on the quality of lubricating oils. For this purpose, the reactions of various MAAE with nitriles of acrylic, methacrylic and crotonic acids have been studied. It was found that in the presence of triethylamine as a catalyst, the reactions of MAAE with nitriles of these acids proceed contrary to Markovnikov's rule, resulting in the formation of the corresponding 2-cyanoalkylalkoxycarbonylmethyl sulfides:

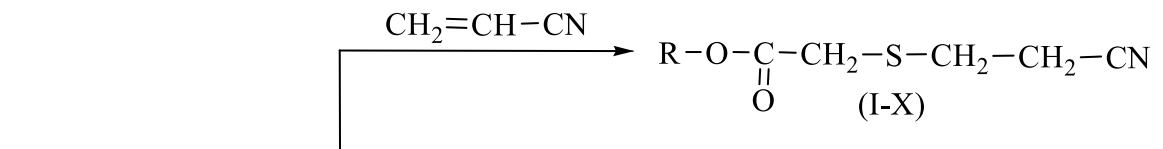

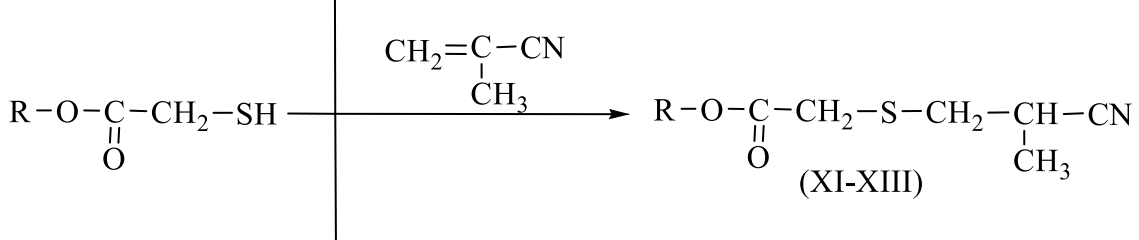

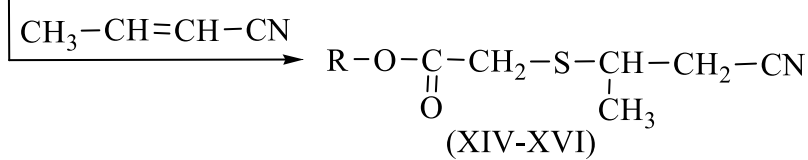

$$
\begin{aligned}
& \mathrm{R}=\mathrm{C}_{2} \mathrm{H}_{5}(\mathrm{I}), \mathrm{C}_{3} \mathrm{H}_{7} \text { (II), } i-\mathrm{C}_{3} \mathrm{H}_{7} \text { (III), } \mathrm{C}_{4} \mathrm{H}_{9}(\mathrm{IV}), i-\mathrm{C}_{4} \mathrm{H}_{9}(\mathrm{~V}), \mathrm{C}_{5} \mathrm{H}_{11}(\mathrm{VI}), \mathrm{C}_{6} \mathrm{H}_{13}(\mathrm{VII}), \\
& \mathrm{C}_{7} \mathrm{H}_{15} \text { (VIII), } \mathrm{C}_{8} \mathrm{H}_{17} \text { (IX), }\left(\mathrm{CH}_{2}\right)_{5} \mathrm{CH}(\mathrm{X}), \mathrm{C}_{2} \mathrm{H}_{5} \text { (XI), } i-\mathrm{C}_{3} \mathrm{H}_{7} \text { (XII), } \mathrm{C}_{4} \mathrm{H}_{9} \text { (XIII), } \\
& \mathrm{C}_{2} \mathrm{H}_{5} \text { (XIV), } i-\mathrm{C}_{3} \mathrm{H}_{7} \text { (XV), } \mathrm{C}_{4} \mathrm{H}_{9} \text { (XVI) }
\end{aligned}
$$




\section{Experimental part}

To obtain 2-cyanoalkylalkoxycarbonylmethyl sulfides (I-XVI), MAAE were used as starting products, which were synthesized by the reaction of mercaptoacetic acid with the corresponding alcohols in the presence of $\mathrm{HCl}$ as a catalyst, according to the method described in [5]. The IR spectra of the substances were recorded on a UR-20 device with a thin layer. The PMR spectra were recorded on a Varian T-60 spectrometer with an operating frequency of $60 \mathrm{MHz}$ in a $\mathrm{CCl}_{4}$ solution, the internal standard was TMS.

General procedure for the synthesis of compounds (I-XVI). $0.005 \mathrm{~mol}$ of triethylamine is added with stirring to a mixture of $0.1 \mathrm{~mol}$ of mercaptoacetic acid ester and $0.1 \mathrm{~mol}$ of unsaturated nitrile and incubated for 3 hours at 70$80^{\circ} \mathrm{C}$. 2-Cyanoalkylalkoxycarbonylmethyl sulfide is isolated by distillation in vacuum. The synthesized sulfides (I-XVI) are colorless liquids with a characteristic odor. They are highly soluble in organic solvents, but insoluble in water.

The physical-chemical characteristics of the synthesized sulfides are presented in Table 1.

\section{Results and discussion}

The procedure for the addition of MAAE to unsaturated acid nitriles was confirmed by an independent synthesis:

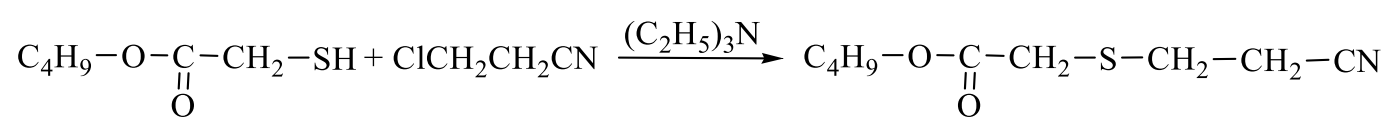

The physical constants and spectral characteristics of 2-cyanoethylbutoxycarbonylmethyl sulfide and the product obtained by the reaction of mercaptoacetic acid butyl ester with chloropropionic acid nitrile in the presence of an equimolar amount of triethylamine are identical. IR and NMR spectral data also confirm the structure of the synthesized compounds.

As a specific object of detailed discussion, let us consider the spectra of 2-cyanoethylcyclohexyloxycarbonylmethyl sulfide (X).<smiles>N#CCCSCC(=O)OC1CCCCC1</smiles>

A

The absence of an absorption band at $1380 \mathrm{~cm}^{-1}$, characteristic of the $\mathrm{CH}_{3}$ group in the IR spectrum, indicates the formation of a product corresponding to structure A.

In the PMR spectrum of compounds (X) (Figure 2), the protons of the methylene groups
Everything that will be said about this product applies equally to other products in this series. The IR spectra of compounds (X) (Figure 1) contain absorption bands in the fields of 2260, 1730 , and $1290 \mathrm{~cm}^{-1}$, which indicates the presence of $\mathrm{C} \equiv \mathrm{N}, \mathrm{C}=\mathrm{O}$, and $\mathrm{C}-\mathrm{O}$ bonds, respectively [6].

In the case of the interaction of the cyclohexyl ester of mercaptoacetic acid with acrylonitrile, the formation of two isomeric products of the following structures is possible:<smiles>CC(C#N)SCC(=O)OC1CCCCC1</smiles>

of the cyclohexyl ring are observed as a multiplet at $\delta=1-2.1 \mathrm{ppm}$. The proton of the methine group of the cyclohexyl ring gives a multiplet at $\delta=4.4-4.8 \mathrm{ppm}$. The protons of the $\mathrm{SCH}_{2} \mathrm{COOR}$ group appear as a singlet with a chemical shift of $\delta=3.3 \mathrm{ppm}$. 


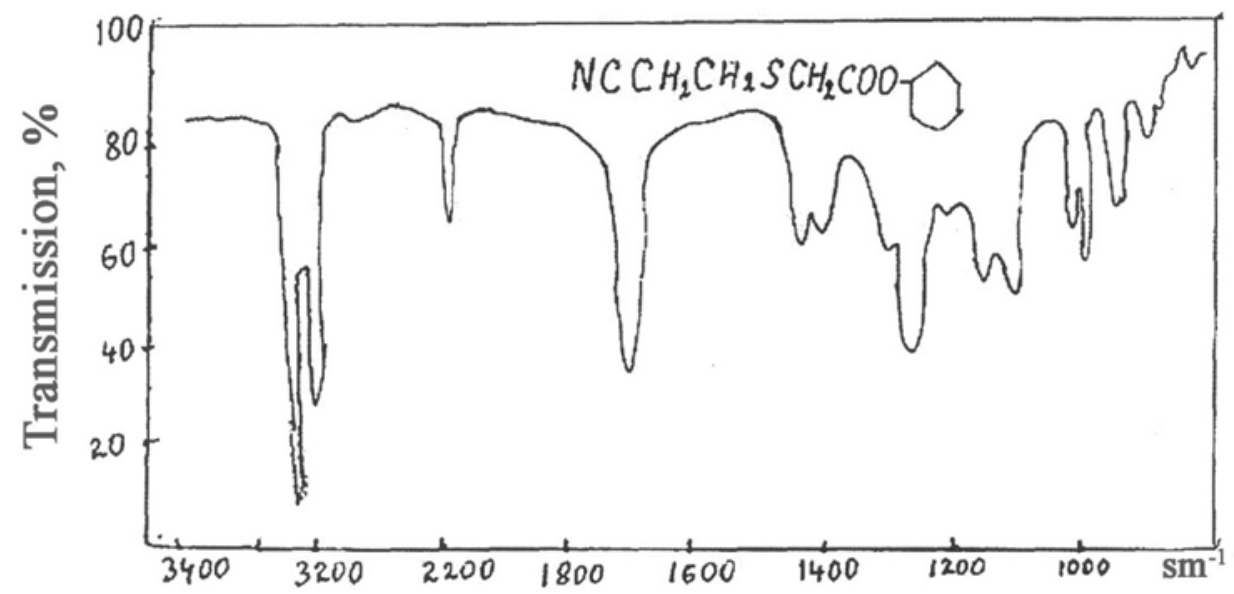

Fig. 1. IR spectrum of 2-cyanoethylcyclohexyloxycarbonylmethyl sulfide (X).

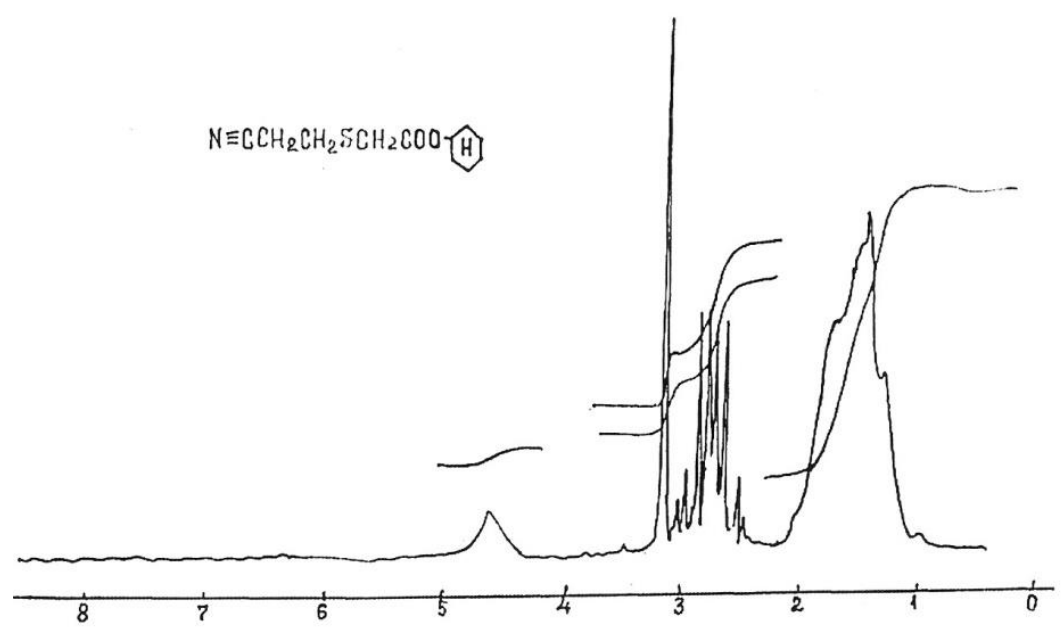

Fig. 2. PMR spectrum of 2-cyanoethylcyclohexyloxycarbonylmethyl sulfide (X). 


\begin{tabular}{|c|c|c|c|c|c|c|c|c|c|c|c|c|c|c|c|}
\hline \multirow{2}{*}{ Compounds } & \multirow{2}{*}{$\begin{array}{c}\text { Yield, } \\
\%\end{array}$} & \multirow{2}{*}{$\begin{array}{l}\text { B.p. (P mm } \\
\text { merc.c.), }{ }^{0} \mathrm{C}\end{array}$} & \multirow{2}{*}{$d_{20}^{4}$} & \multirow{2}{*}{$n_{20}^{d}$} & \multicolumn{2}{|c|}{$\mathrm{MR}_{\mathrm{D}}$} & \multicolumn{4}{|c|}{ Found, $\%$} & \multirow{2}{*}{ Brutto formula } & \multicolumn{4}{|c|}{ Calculated, \% } \\
\hline & & & & & found & calc. & $\mathrm{C}$ & $\mathrm{H}$ & $\mathrm{N}$ & $\mathrm{S}$ & & $\mathrm{C}$ & $\mathrm{H}$ & $\mathrm{N}$ & $\mathrm{S}$ \\
\hline $\mathrm{I}$ & 90 & $101-102(0.4)$ & 1.1290 & 1.4813 & 43.68 & 44.00 & 48.30 & 6.75 & 7.90 & 18.34 & $\mathrm{C}_{7} \mathrm{H}_{11} \mathrm{NO}_{2} \mathrm{~S}$ & 48.53 & 6.40 & 8.08 & 18.51 \\
\hline II & 91 & $116-117(0.3)$ & 1.0975 & 1.4790 & 48.39 & 48.62 & 51.54 & 7.11 & 7.30 & 17.25 & $\mathrm{C}_{8} \mathrm{H}_{13} \mathrm{NO}_{2} \mathrm{~S}$ & 51.31 & 6.99 & 7.48 & 17.12 \\
\hline III & 88 & $106-107(0.5)$ & 1.0877 & 1.4742 & 48.40 & 48.62 & 51.10 & 7.18 & 7.22 & 16.91 & $\mathrm{C}_{8} \mathrm{H}_{13} \mathrm{NO}_{2} \mathrm{~S}$ & 51.31 & 6.99 & 7.48 & 17.12 \\
\hline IV & 90 & $125-130(0.4)$ & 1.0744 & 1.4775 & 52.98 & 53.23 & 53.55 & 7.77 & 6.80 & 16.20 & $\mathrm{C}_{9} \mathrm{H}_{15} \mathrm{NO}_{2} \mathrm{~S}$ & 53.70 & 7.51 & 6.96 & 15.93 \\
\hline $\mathrm{V}$ & 93 & $114-115(0.2)$ & 1.0679 & 1.4754 & 53.10 & 53.23 & 53.94 & 7.72 & 7.14 & 15.75 & $\mathrm{C}_{9} \mathrm{H}_{15} \mathrm{NO}_{2} \mathrm{~S}$ & 53.70 & 7.51 & 6.96 & 15.93 \\
\hline VI & 88 & $136-137(0.2)$ & 1.0546 & 1.4758 & 57.54 & 57.85 & 55.54 & 8.12 & 6.67 & 15.11 & $\mathrm{C}_{10} \mathrm{H}_{17} \mathrm{NO}_{2} \mathrm{~S}$ & 55.78 & 7.96 & 6.50 & 14.89 \\
\hline VII & 92 & $142-143(0.2)$ & 1.0375 & 1.4751 & 62.23 & 62.47 & 57.42 & 8.58 & 6.27 & 14.18 & $\mathrm{C}_{11} \mathrm{H}_{19} \mathrm{NO}_{2} \mathrm{~S}$ & 57.60 & 8.35 & 6.11 & 13.98 \\
\hline VIII & 93 & $154-156(0.3)$ & 1.0256 & 1.4744 & 66.70 & 67.09 & 59.62 & 8.73 & 5.65 & 13.52 & $\mathrm{C}_{12} \mathrm{H}_{21} \mathrm{NO}_{2} \mathrm{~S}$ & 59.22 & 8.69 & 5.75 & 13.17 \\
\hline IX & 84 & $165-166(0.4)$ & 1.0081 & 1.4740 & 71.74 & 71.70 & 60.91 & 9.25 & 5.28 & 12.62 & $\mathrm{C}_{13} \mathrm{H}_{23} \mathrm{NO}_{2} \mathrm{~S}$ & 60.66 & 9.01 & 5.44 & 12.46 \\
\hline $\mathrm{X}$ & 89 & $150-151(0.2)$ & 1.1149 & 1.5014 & 60.10 & 60.27 & 57.83 & 7.61 & 6.41 & 13.67 & $\mathrm{C}_{11} \mathrm{H}_{17} \mathrm{NO}_{2} \mathrm{~S}$ & 58.11 & 7.53 & 6.16 & 14.10 \\
\hline XI & 70 & $161-162(6)$ & 1.1040 & 1.4793 & 48.13 & 48.62 & 51.66 & 7.24 & 7.65 & 17.01 & $\mathrm{C}_{8} \mathrm{H}_{13} \mathrm{NO}_{2} \mathrm{~S}$ & 51.31 & 6.99 & 7.48 & 17.12 \\
\hline XII & 84 & 139-140 (1) & 1.0677 & 1.4722 & 52.81 & 53.23 & 53.24 & 7.60 & 7.18 & 15.62 & $\mathrm{C}_{9} \mathrm{H}_{15} \mathrm{NO}_{2} \mathrm{~S}$ & 53.70 & 7.51 & 6.96 & 15.93 \\
\hline XIII & 87 & $172-173(4)$ & 1.0457 & 1.4730 & 57.76 & 57.85 & 56.14 & 7.82 & 6.82 & 14.95 & $\mathrm{C}_{10} \mathrm{H}_{17} \mathrm{NO}_{2} \mathrm{~S}$ & 55.78 & 7.96 & 6.50 & 14.89 \\
\hline XIV & 72 & $146-147(2)$ & 1.1175 & 1.4825 & 47.82 & 48.62 & 51.12 & 7.18 & 7.30 & 17.24 & $\mathrm{C}_{8} \mathrm{H}_{13} \mathrm{NO}_{2} \mathrm{~S}$ & 51.31 & 6.99 & 7.48 & 17.12 \\
\hline $\mathrm{XV}$ & 85 & $145-146(1.5)$ & 1.0705 & 1.4764 & 53.07 & 53.23 & 53.42 & 7.82 & 6.71 & 16.18 & $\mathrm{C}_{9} \mathrm{H}_{15} \mathrm{NO}_{2} \mathrm{~S}$ & 53.70 & 7.51 & 6.96 & 15.93 \\
\hline XVI & 92 & 169-170 (3) & 1.0511 & 1.4758 & 57.76 & 57.85 & 55.32 & 8.16 & 6.74 & 14.76 & $\mathrm{C}_{10} \mathrm{H}_{17} \mathrm{NO}_{2} \mathrm{~S}$ & 55.78 & 7.96 & 6.50 & 14.89 \\
\hline
\end{tabular}


In the PMR spectrum of compounds (X) (Figure 2), the protons of the methylene groups of the cyclohexyl ring are observed as a multiplet at $\delta=1-2.1 \mathrm{ppm}$. The proton of the methine group of the cyclohexyl ring gives a multiplet at $\delta=4.4-4.8 \mathrm{ppm}$. The protons of the $\mathrm{SCH}_{2} \mathrm{COOR}$ group appear as a singlet with a chemical shift of $\delta=3.3 \mathrm{ppm}$.

The resonances of the signals of the protons of two methylene groups of the $\mathrm{N} \equiv \mathrm{C}-\mathrm{CH}_{2}-\mathrm{CH}_{2}-\mathrm{S}$ fragment appear as triplets with chemical shifts $\delta a=2.75$ and $\delta b=2.9 \mathrm{ppm}$. The absence of resonance signals of protons from the methyl and methine groups of the $\mathrm{N} \equiv \mathrm{C}-\mathrm{CH}_{2}-\mathrm{CH}_{2}-\mathrm{S}$ fragment, which would have occurred during the formation of a product corresponding to structure B, also confirms the structure of the synthesized compounds [7].

Thus, the MAAE cyanalkylation method has been used to synthesize oxygen-, sulfur- and nitrogen-containing organic compounds that are of interest as potential additives to lubricating oils.

\section{References}

1. Sintez sulfidov, tiofenov i tiolov. Otv. red. Karaulova E.N. M.: Nauka, 1988. 208 s.

2. Khimiya organicheskikh soyedineniy sery. Pod. red. L.I.Belenkogo. M.: Khimiy, 1988. 320 s.

3. Sardarova S.A., Osmanova S.F., Mamedov F.A., Qamidova Sh.Y. Sintez i issledovaniye slojnikh efirov 1,1-bis-(hidroksikarbonilmetiltio)-1-ariletanov. Khimicheskie Problemi 2015. No 3. C. 319-322.

4. Guseinov K.Z. Funktsionalniye proizvodniye tiolov i fenolov $\mathrm{v}$ kachestve prisadok $\mathrm{k}$ smazochnym maslam i toplivam. Dis....dokt. khim. nauk. Baku: In-t Khimii Prisadok AN Azerb.SSR, 1991. $471 \mathrm{~s}$.

5. Guseinov K.Z., Gambarov D.G., Mirzoeva M.A., Mamedov F.N., Fati-zade R.F. Sintez efirov tioglikolevoy kisloty i primeneniye ikh v analiticheskoy khimii. Azerb. khim. jurn. 1977. № 6. S. 103-107.

6. Nakanisi K. Infrakrasniye spektry i stroyeniye organicheskikh soyedineniy. M.: Mir, 1965. $216 \mathrm{~s}$.

7. Ionin B.I., Yershov B.A., Koltsov A.I. YAMR spektroskopiya $\mathrm{V}$ organicheskoy khimii. L.: Khimiya, 1983. $269 \mathrm{~s}$.

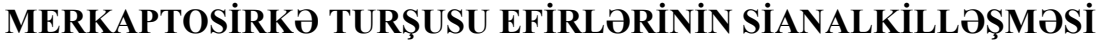

\section{Q.Z.Hüseynov, M.Ө.Mirzəyeva, P.Ө.Đliyev}

Trietilaminin katalizator kimi iştirakı ilə merkaptosirkə turşusaunun efirləri akril-, metakril- və kroton turşularının nitrilləri ilə asan birləşmə reaksiyasına daxul olurlar. Birləşmə reaksiyası Markovnikov qaydasının əksinə gedir və nəticədə müvafiq 2-sianalkilalkoksikarbonilmetilsulfidlər əmələ gəlir.

Açar sözlar: merkaptosirka turşusunun efirlari, sulfid, akril-, metakril- və kroton turşularının nitrillari.

\section{ЦИАНАЛКИЛИРОВАНИЕ ЭФИРОВ МЕРКАПТОУКСУСНОЙ КИСЛОТЫ}

\section{К.З.Гусейнов, М.А.Мирзоева, П.А.Алиев}

Присоединение эфиров меркаптоуксусной кислоты (ЭМУК) к нитрилам акрил-, метакрил- и кротоновой кислот легко происходит в присутствии триэтиламина в качестве катализатора с образованием соответствующих 2цианоалкилалкоксикарбонилметилсульфидов.

Ключевые слова: эфиры меркаптоуксусной кислоты, сульфид, нитрильь акрил-, метакрил- и кротоновой кислот. 